\title{
Case Study for Student Satisfaction of Munzur University
}

\author{
Eylem Yalçınkaya Önder*, Leyla Çiftçioğlu \\ Munzur University, Department of Chemical Engineering, Tunceli, Turkey \\ *eylemyalcinkaya@munzur.edu.tr (iD) \\ Received date: 17.11.2017, Accepted date: 25.04 .2018
}

\begin{abstract}
The aim of this study is to get views of 4th year undergraduate students (including students in extending section) studying at engineering faculty about the University and the program they enrolled. The sample of the study is 232 students attending the final year of engineering faculty at 2015-2016 fall semesters. 23 of these students were studying in Chemical Engineering, 20 of these students were studying in Food Engineering, 29 of these students were studying in Mechanical Engineering, 54 of these students were studying in Computer Engineering, 36 of these students were studying in Civil Engineering, 67 of these students were studying in Electrical-Electronics Engineering, 3 of these students were studying in Environmental Engineering. In order to get students' views on university and the program they enrolled, the survey questionnaire consisting of 50 multiple-choice questions was developed by last year chemical engineering student. This questionnaire survey was prepared taking into consideration the student satisfaction survey of other universities. The content analysis of the developed survey questionnaire was made conducted by five faculty members and necessary arrangements were made in accordance with the recommendations of the faculty members. The findings are expected to be a useful guide for the academic institution.
\end{abstract}

Keywords: Attitude, engineering faculty department, Munzur University, perceived service quality, student satisfaction, questionnaire survey, university

\section{Munzur Üniversitesi Öğrenci Memnuniyeti Örnek Olay İncelemesi}

$\ddot{O ̈ z}$

Bu çalışmanın amacı Munzur Üniversitesi mühendislik fakültesinde okuyan son sınıf lisans öğrencilerinin (bölümü uzatan öğrenciler de dahil) öğrenim gördükleri üniversite ve program hakkındaki görüşlerini almaktır. Bu çalışmanın örneklemini 2015-2016 güz döneminde mühendislik fakültesine devam eden son sınıf 232 öğrenci oluşturmaktadır. Bu öğrencilerin 23'ü Kimya Mühendisliği, 20'si Gıda Mühendisliği, 29’u Makine Mühendisliği, 54'ü Bilgisayar Mühendisliği, 36'sı İnşaat Mühendisliği, 67'si Elektrik-Elektronik Mühendisliği, 3'ü ise Çevre Mühendisliği'nde öğrenim görmektedir. Öğrencilerin okudukları üniversite ve okudukları program hakkındaki görüşlerini almak amacıyla Kimya Mühendisliği son sınıf öğrencisi tarafından 50 soruluk çoktan seçmeli sorudan oluşan bir anket geliştirilmiştir. Bu anket diğer üniversitelerin öğrenci memnuniyeti anketleri dikkate alınarak hazırlanmıştır. Geliştirilen anketin içerik analizi 5 öğretim üyesi tarafından yapılmış olup, öğretim üyelerinin önerileri doğrultusunda gerekli düzenlemeler yapılmıştır. Bulguların akademik kurum için faydalı bir kılavuz olması beklenmektedir.

Anahtar Kelimeler: Algılanan hizmet kalitesi, anket, Munzur Üniversitesi, mühendislik fakültesi, öğrenci memnuniyeti, tutum, üniversite 


\section{DOI: 10.29132/ijpas.354981}

\section{INTRODUCTION}

Today, all over the world, students' opinions on every aspect of academic life are searched through satisfaction surveys. It is this student satisfaction survey, within the context of Munzur University Engineering Faculty that this paper addresses.

Data have been gathered for years systematically in order to improve the quality of universities (Singh, 2002). Student satisfaction should be assessed carefully by the university because of the rivalry between universities, and the importance of education a striking service (Ling et al., 2010). In Longman Dictionary English online, satisfaction is defined as "a feeling of happiness or pleasure because you have achieved something or got what you wanted" (Ho and Dang, 2017). Kotler and Clarke (1987) characterized "satisfaction as a state felt by a person who has experience performance or an outcome that fulfill his or her expectation". Mamun, Soumana, and Khan (2017) had a similar view that "satisfaction of student has been viewed as a vital factor regarding quality of learning approach and a key factor in the success of learning programs'. On the other hand, Cheng et al. (2016) clearly indicated that 'satisfaction is not necessarily perceived as an indicator of quality education'. Students' expectations and their preconceived beliefs have an impact on the levels of student satisfaction. Likewise, Elliot and Heavly (2001) stated that students' satisfaction 'as a shortterm attitude, resulting from an evaluation of a students' educational experiences'. Williams (2013, p. 99) hold a view that surveys of student satisfaction mainly measure 'how students subjectively feel at a particular point in time, their success in the programme to date (in terms of grades) and the extent to which any demands they have made on lecturers have been met'.

Palacio et al. (2002) studied the image of universities both in its cognitive and affective dimensions and of analyzing its relationship with the students' satisfaction with the university. Both of those components influence the forming of the overall image of the university and the cognitive, affective and overall images have a statistically significant effect on students' satisfaction with the university. The literature has revealed various factors as determinants of student satisfaction; some of them related to the characteristics and behavior of the students, while others are related to the training experience or the functioning of the universities. Sapri et al. (2009) also stressed that different cultures and procedures influence their attitudes towards education in universities.

Satisfaction of students is a multifaceted process influenced by different factors. According to Elliot and Shin (2002), the level of student satisfaction is based on the learning experiences, services, and facilities students experience in the learning process. Poon (2017) established an evaluation of graduate built environment student satisfaction in the UK and identified six student satisfaction factors which are/including 'quality of staff and course', 'student learning environment', 'personal development of students', 'student services', 'appropriate assessment' and 'clear expectation'. In this study, 'quality of staff and the course' was found as the most important factor influencing built environment student satisfaction. 'Quality of staff and course' was determined the most important factor influencing built environment student satisfaction. Except all factors, it was found that 'attendance type', a demographic factor, had a negative effect on the satisfaction of the students. Bini and Masserini (2016) supports the Poon's study (2017) in terms of the quality effect on students' satisfaction, they said that students' overall satisfaction is positively associated with perceived quality. Marsh and Roche (2000) mentioned that it would be beneficial to raise the quality of teaching by revealing student views on university teaching. Khosravi et al. (2013) determined seven factors affecting student satisfaction of a university. These are academic advising effectiveness, campus support services, campus life, responsiveness to diverse populations, safety \& security, campus climate, financial aid effectiveness. Evidence indicated that students view academic advising as an important needed service.

Douglas et al. (2006) designed and used of a questionnaire to measure student satisfaction and found that the most important aspects were those related to teaching and learning, while the least important were those related with the physical facilities. On the other hand, determining students' satisfaction is not a simple matter, actually it is the perception of the students measured. Figuring out the satisfaction of the students with the services and facilities in universities and departments will assist the related institution in order to determine their strengths and opportunities that could be empowered. Therefore, there should be in deep prospecting about the experience of the students (Uddin et al. 2017). In addition, student satisfaction is a good predictor about 
DOI: 10.29132/ijpas.354981

the quality of learning, success of learning programs to a certain extent. National Student Survey (NSS) is an important tool used to measure teaching quality in UK higher education. Therefore, all universities are interested in possible strategies to maximize NSS scores and attract better students (Lenton, 2015). 'The assessment of student opinions and attitudes is a modern-day necessity as institutions of higher education are challenged by a climate of decreased funding, demands for public accountability, and increased competition for student enrollments' (Elliot $\&$ Shin, 2002).

This paper's contribution to literature is in identifying some important elements for enhancing student satisfaction which universities can take on board for developing a strategy to enhance student satisfaction. Developing universities such as Munzur University can be benefited from this kind of researches for the determination of the strengths and weaknesses of the institution. Consequently, the aim of this study was determined to get opinions of senior engineering faculty students about the university and the department they are studying.

\section{MATERIALS AND METHOD}

In literature, there are many researches that had focused on measuring students' satisfaction (Elliott and Shin, 2002; Price ., 2000; Uddin ., 2017). This measurement instrument consisting of 50 questions was developed by last year chemical engineering department student under the supervision of a teaching member to get students' opinions about the teaching program and the university they are studying This survey consists of questions about demographic data, university experience and student overall satisfaction. While the first two parts were measured with multiple choice questions, the third part was measured by type Likert Type Scale. This 5-point Likert type scale including 22 items from 'very low' to 'very high'. The reliability of this test was found to be 0.854. Since Likert type scales included in nonparametric data group, Kruskal Wallis test was applied for the analysis of 22 items. This method is the non-parametric counterpart of the one-way analysis of variance (Çimen, 2015).

The content analysis of the developed survey has been conducted by five faculty members and necessary arrangements were made in accordance with the recommendations of them. The total number of students studying in the last grade in the mentioned teaching programs during the study period is around 575.232 of them were participated to the study. Many of the students (173 students) were in the age range of $20-25$ years. Approximately $73 \%$ of the students were male and $26 \%$ were female.

\section{RESULTS}

The descriptive data obtained in this study were analyzed with SPSS 18 (Statistical Package for the Social Sciences). Descriptive statistics was performed from question 1 to question 28 and Kruskal Wallis analysis was conducted for the likert type questions (including questions 29 to 50) to gain demographic characteristics of the respondents, and their level of satisfaction. Kruskal Wallis analysis showed that whether at least one of department is different from others for the related questions. For the questions with significant results in the Kruskal Wallis analysis, the Mann-Whitney analysis was run. The Mann-Whitney test is a non-parametric test that looks for differences between two independent samples. The Mann-Whitney test was used to determine whether there was a significant difference between the departments for the relevant questions. Table 1 below gives the distribution of the students according to their departments and learning types.

Table 1. Distribution of undergraduate engineering students by departments

\begin{tabular}{lccc}
\hline \multicolumn{3}{c}{ Type of Learning } & \\
\hline Department & $\begin{array}{c}\text { Daytime } \\
\text { Educ. }\end{array}$ & $\begin{array}{c}\text { Evening } \\
\text { Educ. }\end{array}$ & Total \\
\hline $\begin{array}{l}\text { Chemical } \\
\text { Engineering }\end{array}$ & 20 & 3 & 23 \\
\hline $\begin{array}{l}\text { Food } \\
\text { Engineering }\end{array}$ & 12 & 8 & 20 \\
\hline $\begin{array}{l}\text { Mechanical } \\
\text { Engineering }\end{array}$ & 16 & 13 & 29 \\
\hline $\begin{array}{l}\text { Computer } \\
\text { Engineering }\end{array}$ & 27 & 27 & 54 \\
\hline $\begin{array}{l}\text { Civil } \\
\text { Engineering }\end{array}$ & 21 & 14 & 35 \\
\hline $\begin{array}{l}\text { Electrical } \\
\text { Engineering }\end{array}$ & 35 & 32 & 67 \\
\hline $\begin{array}{l}\text { Environmental } \\
\text { Engineering }\end{array}$ & 1 & 2 & 3 \\
\hline \begin{tabular}{l} 
Total \\
\hline
\end{tabular} & $132(57 \%)$ & 99 & 231 \\
\hline
\end{tabular}


DOI: 10.29132/ijpas.354981

Table 2. Distribution of undergraduate engineering students' high school types according to their departments

\begin{tabular}{|c|c|c|c|c|c|c|c|}
\hline \multirow[b]{2}{*}{ Department } & \multicolumn{7}{|c|}{$\begin{array}{c}\text { High School Type } \\
\end{array}$} \\
\hline & $\begin{array}{l}\text { Public } \\
\text { School }\end{array}$ & $\begin{array}{l}\text { Labor } \\
\text { School }\end{array}$ & $\begin{array}{c}\text { Anatolian } \\
\text { School }\end{array}$ & $\begin{array}{l}\text { Private } \\
\text { School }\end{array}$ & $\begin{array}{l}\text { Science } \\
\text { School }\end{array}$ & Others & Total \\
\hline Chemical Engineering & 16 & 2 & 2 & 1 & 0 & 2 & 23 \\
\hline Food Engineering & 12 & 1 & 6 & 1 & 0 & 0 & 20 \\
\hline Mechanical Engineering & 22 & 1 & 6 & 0 & 0 & 0 & 29 \\
\hline Computer Engineering & 34 & 7 & 13 & 0 & 0 & 0 & 54 \\
\hline Civil Engineering & 19 & 3 & 11 & 2 & 0 & 1 & 36 \\
\hline $\begin{array}{l}\text { Electrical and Electronics } \\
\text { Engineering }\end{array}$ & 31 & 18 & 15 & 1 & 1 & 1 & 67 \\
\hline $\begin{array}{l}\text { Environmental } \\
\text { Engineering }\end{array}$ & 3 & 0 & 0 & 0 & 0 & 0 & 3 \\
\hline Total & $\begin{array}{c}137 \\
(59 \%)\end{array}$ & $32(14 \%)$ & $53(23 \%)$ & 5 & 1 & 4 & 232 \\
\hline
\end{tabular}

The students were asked about the order of preference of the department that they are studying in the university entrance exam. The distribution of the students' preference order according to their departments was given in Table 3. Data indicated almost half of the students' (47\%) department was one of the top three preferences in the university exam. It can be said that most of the students prefer the program which they study intentionally or willingly.

Table 3. Undergraduate engineering students' department preference order

\begin{tabular}{|c|c|c|c|c|c|}
\hline \multirow[b]{2}{*}{ Department } & \multicolumn{5}{|c|}{ Department Preference Order } \\
\hline & Top 3 preference & $\begin{array}{l}\text { Between } 4^{\text {th }} \\
\text { and } 6^{\text {th }} \\
\text { preferences }\end{array}$ & $\begin{array}{l}\text { Between } 6^{\text {th }} \text { and } \\
10^{\text {th }} \text { preferences }\end{array}$ & $\begin{array}{c}\text { After } 10^{\text {th }} \\
\text { preference }\end{array}$ & Total \\
\hline Chemical Engineering & 10 & 6 & 2 & 5 & 23 \\
\hline Food Engineering & 6 & 3 & 6 & 5 & 20 \\
\hline Mechanical Engineering & 17 & 4 & 1 & 7 & 29 \\
\hline Computer Engineering & 26 & 13 & 5 & 10 & 54 \\
\hline Civil Engineering & 19 & 6 & 4 & 6 & 35 \\
\hline $\begin{array}{l}\text { Electrical and Electronics } \\
\text { Engineering }\end{array}$ & 30 & 14 & 10 & 13 & 67 \\
\hline $\begin{array}{l}\text { Environmental } \\
\text { Engineering }\end{array}$ & 1 & 0 & 0 & 2 & 3 \\
\hline Total & $109(47 \%)$ & $46(20 \%)$ & 28 & $48(20 \%)$ & 231 \\
\hline
\end{tabular}

Students were asked to select the most important three reasons to choose their departments as numbering 1,2,3 according to their priority order. The numbers presented in Tables 4, 5 and 6 indicated the reasons why undergraduate engineering faculty students preferred the program they are studying. According to Appendix 1, the first reason why students chose their departments they are currently studying was that they had considered their department choices fit their abilities and suited their talents. The second reason was that students thought that they would find a job easier after they graduate (see Appendix 2). The third reason was that they thought that the program they are studying would yield more welfare (see Appendix 3). According to Table 4, majority of the students $(67 \%)$ stated that they were satisfied with the department they are studying. 
Table 4. Student satisfaction table according to students' department

\begin{tabular}{lcccc}
\hline & \multicolumn{2}{c}{ Department Satisfaction } \\
\hline Department & Yes & No & Undecided & Total \\
\hline Chemical Engineering & 10 & 5 & 8 & 23 \\
\hline Food Engineering & 11 & 7 & 2 & 20 \\
\hline Mechanical Engineering & 21 & 4 & 4 & 29 \\
\hline Computer Engineering & 35 & 12 & 7 & 54 \\
\hline Civil Engineering & 29 & 3 & 4 & 67 \\
\hline $\begin{array}{l}\text { Electrical and Electronics } \\
\text { Engineering }\end{array}$ & 49 & 10 & 8 & 3 \\
\hline Environmental Engineering & 1 & 0 & 2 & 232 \\
\hline Total & $156(67 \%)$ & $41(17 \%)$ & $35(15 \%)$ & \\
\hline
\end{tabular}

Despite undergraduate students were satisfied with the department they have been studying, half of the students in total considered the education they received to be poor. As detailed shown in Table 5, approximately $30 \%$ (68 students) of the students in total have stated the quality of the education they received as moderate.

Table 5. Students' general evaluation of the education they receive according to the departments

\begin{tabular}{lcccccc}
\hline & \multicolumn{7}{c}{ General Evaluation of the Education They Receive } \\
\hline & Very good & Good & Average & Poor & Very poor & Total \\
\hline Department & 0 & 4 & 10 & 3 & 6 & 23 \\
\hline Chemical Engineering & 1 & 4 & 7 & 3 & 5 & 20 \\
\hline Mood Engineering & 0 & 6 & 11 & 7 & 5 & 29 \\
\hline Computer Engineering & 3 & 7 & 11 & 13 & 20 & 54 \\
\hline Civil Engineering & 3 & 13 & 8 & 9 & 3 & 36 \\
\hline $\begin{array}{l}\text { Electrical and Electronics } \\
\text { Engineering }\end{array}$ & 1 & 6 & 18 & 21 & 21 & 67 \\
\hline $\begin{array}{l}\text { Environmental } \\
\text { Engineering }\end{array}$ & 0 & 0 & 3 & 0 & 0 & 3 \\
\hline Total & 8 & $40(17 \%)$ & $68(29 \%)$ & $56(24 \%)$ & $60(26 \%)$ & 232 \\
\hline
\end{tabular}

Students were asked whether they have 6 clearly indicates that about $77 \%$ of the students performed enough practice (project, homework, thought that they had not practiced enough related to laboratory, etc.) for the field they are studying. Table their profession.

Table 6. Undergraduate engineering students' field practice evaluation according to the departments

\begin{tabular}{|c|c|c|c|c|}
\hline & \multicolumn{4}{|c|}{ Field Practice (Project, Homework, Laboratory, etc.) } \\
\hline Department & Yes & No & Undecided & Total \\
\hline Chemical Engineering & 4 & 15 & 4 & 23 \\
\hline Food Engineering & 1 & 16 & 3 & 20 \\
\hline Mechanical Engineering & 5 & 16 & 8 & 29 \\
\hline Computer Engineering & 6 & 43 & 5 & 54 \\
\hline Civil Engineering & 2 & 30 & 4 & 36 \\
\hline $\begin{array}{l}\text { Electrical and Electronics } \\
\text { Engineering }\end{array}$ & 2 & 58 & 7 & 67 \\
\hline $\begin{array}{l}\text { Environmental } \\
\text { Engineering }\end{array}$ & 1 & 1 & 1 & 3 \\
\hline Total & 21 & $179(77 \%)$ & 32 & 232 \\
\hline
\end{tabular}


DOI: 10.29132/ijpas.354981

Students were questioned whether they joined in vocational activities in their department. Table 7 revealed that most of the field practice were carried out by the lecturers of chemical engineering department among the other engineering faculty departments.

Table 7. Students' evaluation of professional activities according to the departments

\begin{tabular}{lccc}
\hline & \multicolumn{2}{c}{ Vocational Activity (Technical trip, seminar etc.) } \\
\hline Department & Yes & No & Total \\
\hline Chemical Engineering & $8(34 \%)$ & 15 & 23 \\
\hline Food Engineering & 0 & 20 & 20 \\
\hline Mechanical Engineering & 6 & 23 & 29 \\
\hline Computer Engineering & $12(22 \%)$ & 42 & 54 \\
\hline Civil Engineering & 3 & 33 & 36 \\
\hline $\begin{array}{l}\text { Electrical and Electronics } \\
\text { Engineering }\end{array}$ & 5 & 62 & 67 \\
\hline Environmental Engineering & 1 & 2 & 3 \\
\hline Total & 35 & 197 & 232 \\
\hline
\end{tabular}

Students were asked whether they follow-up professional publications, journals, or documents, etc. As shown in Table 8, while $67 \%$ of the students (156 students) selected the option "Yes" and 33\% of the students (76 students) marked "No".

Table 8. Students follow-up professional publication, journal or document

\begin{tabular}{lccc}
\hline & & Professional publication, journal, or document & \\
\hline Department & Yes & No & Total \\
\hline Chemical Engineering & 15 & 8 & 23 \\
\hline Food Engineering & 11 & 9 & 20 \\
\hline $\begin{array}{l}\text { Mechanical } \\
\text { Engineering }\end{array}$ & 15 & 14 & 29 \\
\hline $\begin{array}{l}\text { Computer Engineering } \\
\text { Civil Engineering }\end{array}$ & 41 & 13 & 54 \\
\hline $\begin{array}{l}\text { Electrical and } \\
\begin{array}{l}\text { Electronics } \\
\text { Engineering }\end{array}\end{array}$ & 23 & 13 & 36 \\
\hline $\begin{array}{l}\text { Environmental } \\
\text { Engineering }\end{array}$ & 49 & 18 & 67 \\
\hline Total & 2 & 1 & 3 \\
\hline
\end{tabular}

After they were asked whether they follow professional documents related to their area of specialization, the other vocational activities were examined other than the training provided by the department. It was determined that students in general mostly pursuing vocational books about their fields (see Table 9). 
Table 9. Students vocational activities

\begin{tabular}{|c|c|c|c|c|c|}
\hline \multirow[b]{2}{*}{ Department } & \multicolumn{5}{|c|}{ Vocational activity } \\
\hline & $\begin{array}{c}\text { Attending } \\
\text { congress, } \\
\text { symposium etc. }\end{array}$ & $\begin{array}{c}\text { Following } \\
\text { national and } \\
\text { international } \\
\text { publications }\end{array}$ & $\begin{array}{c}\text { Reading } \\
\text { vocational } \\
\text { books }\end{array}$ & $\begin{array}{c}\text { Do not spare } \\
\text { time } \\
\text { for other studies } \\
\text { except for } \\
\text { studying }\end{array}$ & Total \\
\hline Chemical Engineering & 1 & 3 & 6 & 13 & 23 \\
\hline Food Engineering & 1 & 1 & 10 & 8 & 20 \\
\hline $\begin{array}{l}\text { Mechanical } \\
\text { Engineering }\end{array}$ & 3 & 5 & 9 & 12 & 29 \\
\hline $\begin{array}{l}\text { Computer } \\
\text { Engineering }\end{array}$ & 4 & 8 & 25 & 17 & 54 \\
\hline Civil Engineering & 2 & 3 & 15 & 16 & 36 \\
\hline $\begin{array}{l}\text { Electrical } \\
\text { Electronics } \\
\text { Engineering }\end{array}$ & 5 & 8 & 31 & 23 & 67 \\
\hline $\begin{array}{l}\text { Environmental } \\
\text { Engineering }\end{array}$ & 0 & 0 & 3 & 0 & 3 \\
\hline Total & 16 & 28 & $99(42 \%)$ & $89(38 \%)$ & 232 \\
\hline
\end{tabular}

Students were asked whether they had received support by the department they are studying in finding an internship place. Interestingly, 183 students out of 232 stated that they found their internship places on their own efforts. As seen in Table 10, computer engineering department was the most supportive department in this subject of matter.

Table 10. Department support for finding internship place

\begin{tabular}{lccc}
\hline & \multicolumn{2}{c}{ Department support for finding internship place } \\
\hline Department & Yes & No & Total \\
\hline Chemical Engineering & $6(26 \%)$ & 17 & 23 \\
\hline Food Engineering & $4(20 \%)$ & 16 & 20 \\
\hline Mechanical Engineering & 4 & 25 & 29 \\
\hline Computer Engineering & $20(37 \%)$ & 34 & 54 \\
\hline Civil Engineering & 6 & 30 & 36 \\
\hline $\begin{array}{l}\text { Electrical and Electronics } \\
\text { Engineering }\end{array}$ & 8 & 59 & 67 \\
\hline Environmental Engineering & 1 & 2 & 3 \\
\hline Total & $49(21 \%)$ & $183(79 \%)$ & 232 \\
\hline
\end{tabular}

The students were asked whether they found the number of teaching staff in their departments to be sufficient. It was determined that $69 \%$ of last grade engineering faculty students did not find the number of teaching staff to be sufficient. The departments where the number of teaching staff were the most adequate according to senior students are as follows: Food Engineering Department (40\%), Chemical Engineering Department (39\%), and Mechanical Engineering Department (38\%), respectively (see Table 11). 
DOI: 10.29132/ijpas.354981

Table 11. Adequacy of number of academic staff according to departments

\begin{tabular}{lcccc}
\hline & \multicolumn{2}{c}{ Adequacy of Number of Academic Staff } \\
\hline Department & Yes & No & Partially & Total \\
\hline Chemical Engineering & $9(39 \%)$ & 8 & 6 & 23 \\
\hline Food Engineering & $8(40 \%)$ & 5 & 7 & 20 \\
\hline Mechanical Engineering & $11(38 \%)$ & 13 & 5 & 29 \\
\hline Computer Engineering & 6 & 44 & 4 & 54 \\
\hline Civil Engineering & 2 & 30 & 3 & 35 \\
\hline $\begin{array}{l}\text { Electrical and Electronics } \\
\text { Engineering }\end{array}$ & 1 & 59 & 7 & 67 \\
\hline Environmental Engineering & 1 & 1 & 1 & 3 \\
\hline Total & 38 & $160(69 \%)$ & 33 & 231 \\
\hline
\end{tabular}

The last grade engineering faculty students were asked whether they had difficulty to access the instructors out of class hours. The related answers were presented in Table 12. Accordingly, it was seen that $40 \%$ (92 students) of the students in total had difficulty in this regard.

Table 12. Access to instructor according to last grade undergraduate students

\begin{tabular}{lcccc}
\hline & \multicolumn{2}{l}{ Access to instructor } & Total \\
\hline Department & Yes & No & Partially & 8 \\
\hline Chemical Engineering & 4 & 11 & 7 & 20 \\
\hline Food Engineering & 2 & 11 & 9 & 29 \\
\hline Mechanical Engineering & 5 & 15 & 11 & 54 \\
\hline Computer Engineering & 16 & 27 & 11 & 35 \\
\hline Civil Engineering & 15 & 9 & 22 & 37 \\
\hline $\begin{array}{l}\text { Electrical and Electronics } \\
\text { Engineering }\end{array}$ & 28 & 17 & & \\
\hline $\begin{array}{l}\text { Environmental } \\
\text { Engineering }\end{array}$ & 1 & 2 & & 231 \\
\hline Total & 71 & $92(40 \%)$ & 68 & \\
\hline
\end{tabular}

The students were asked whether they had trouble with the teaching method of the instructor in the program they were studying. In Table 13, when the students' answers are evaluated; approximately $49 \%$ of them said that they had troubled with the teaching method of the instructor used.

Table 13. The problem with the teaching method used by the lecturer

\begin{tabular}{lcccc}
\hline \multicolumn{4}{c}{ The problem with the teaching method used by the lecturer } \\
\hline $\begin{array}{l}\text { Department } \\
\text { Chemical Engineering }\end{array}$ & Yes & No & Partially & Total \\
\hline Food Engineering & 9 & 6 & 8 & 23 \\
\hline Mechanical Engineering & 4 & 9 & 7 & 20 \\
\hline Computer Engineering & 14 & 7 & 8 & 29 \\
\hline Civil Engineering & 24 & 8 & 5 & 54 \\
\hline $\begin{array}{l}\text { Electrical and Electronics } \\
\text { Engineering }\end{array}$ & 25 & 5 & 15 & 67 \\
\hline Environmental Engineering & 38 & 14 & 2 & 3 \\
\hline Total & $114(49 \%)$ & $50(21 \%)$ & $67(29 \%)$ & 231 \\
\hline
\end{tabular}


DOI: 10.29132/ijpas.354981

Students were asked to choose the two most important problems of the department they are studying numbering the alternatives as 1 and 2 according to their priorities. They specified the one of the most important problem of the departments as the lack of infrastructure (Classes, buildings, etc.). The other was the teaching staffs' inadequacy of field practice (see Appendix 4 and 5).

Despite many of the students (35\%) stated that they would like to work in private sector after graduation, $25 \%$ of them considered to work in the public sector. On the other hand, minority of the students (14\%) would like to have an academic career (see Appendix 6).

Students were asked what their tendency was to choose the same the university if they had a second chance to make university choice. According to Table 14 , the tendency of students to prefer the same university they are studying seems to be very low.

Table 14. The tendency of students to prefer the university they are studying again

\begin{tabular}{lcccccc}
\hline & \multicolumn{6}{c}{ University Choice } \\
\hline & $\begin{array}{c}\text { Very } \\
\text { High }\end{array}$ & High & Average & Low & Very Low & Total \\
\hline Chemical Engineering & 0 & 0 & 3 & 5 & 15 & 23 \\
\hline Food Engineering & 0 & 2 & 4 & 4 & 10 & 20 \\
\hline Mechanical Engineering & 0 & 2 & 7 & 9 & 11 & 29 \\
\hline Computer Engineering & 2 & 6 & 5 & 4 & 37 & 54 \\
\hline Civil Engineering & 2 & 5 & 6 & 7 & 15 & 35 \\
\hline $\begin{array}{l}\text { Electrical and Electronics } \\
\text { Engineering }\end{array}$ & 7 & 5 & 12 & 14 & 29 & 67 \\
\hline Environmental Engineering & 0 & 0 & 0 & 0 & 3 & 3 \\
\hline Total & 11 & 20 & 37 & $43(18 \%)$ & $120(52 \%)$ & 231 \\
\hline
\end{tabular}

Students were asked what if they had a second chance to choose the department they are studying what would be the current preferences of them. A total of 56\% of the students expressed a high likelihood of choosing the same department again (see Table 15). According to Kruskal-Wallis test results top three departments in which students are highly satisfied with their department choice are as follows: Civil Engineering (Mean Rank:136,51), Mechanical Engineering (Mean Rank:124,74) and Electrical Electronics (Mean Rank:119,38).

Table 15. The tendency of students to prefer the department they are studying again

\begin{tabular}{|c|c|c|c|c|c|c|}
\hline \multirow[b]{2}{*}{ Department } & \multicolumn{6}{|c|}{ Department Choice } \\
\hline & Very High & High & Average & Low & Very Low & Total \\
\hline Chemical Engineering & 2 & 4 & 7 & 8 & 2 & 23 \\
\hline Food Engineering & 3 & 2 & 4 & 4 & 7 & 20 \\
\hline Mechanical Engineering & 14 & 6 & 5 & 1 & 3 & 29 \\
\hline Computer Engineering & 16 & 12 & 8 & 7 & 11 & 54 \\
\hline Civil Engineering & $16(45 \%)$ & $11(31 \%)$ & 1 & 2 & 5 & 35 \\
\hline $\begin{array}{l}\text { Electrical and Electronics } \\
\text { Engineering }\end{array}$ & 28 & 15 & 9 & 7 & 7 & 66 \\
\hline Environmental Engineering & 0 & 1 & 0 & 1 & 1 & 3 \\
\hline Total & $79(34 \%)$ & $51(22 \%)$ & 34 & 30 & 36 & 230 \\
\hline
\end{tabular}

In addition, Kruskal-Wallis test results indicated that at least one department is different from the others in terms of the possibility of students' choosing the same department. Mann-Whitney test statistic was run to compare two independent sample comparisons to determine which departments were statistically different from each other in terms of their department satisfaction. 
DOI: 10.29132/ijpas.354981

Mann-Whitney Test Statistics for Table 21

\begin{tabular}{l|l|l}
\hline Department & Mean Rank & Significance \\
\hline Chemical Engineering & $\mathbf{3 0 . 9 6}$ & $\mathbf{p}=\mathbf{0 . 0 0 3}$ \\
\hline Electrical and Electronics Engineering & $\mathbf{4 8 . 6 9}$ & \\
\hline Food Engineering & 29.60 & $\mathrm{p}=0.005$ \\
\hline Electrical and Electronics Engineering & 46.53 & \\
\hline Chemical Engineering & $\mathbf{1 9 . 3 7}$ & $\mathbf{p}=\mathbf{0 . 0 0}$ \\
\hline Civil Engineering & $\mathbf{3 6 . 1 6}$ & \\
\hline Food Engineering & 18.68 & $\mathrm{p}=0.001$ \\
\hline Civil Engineering & 33.33 & \\
\hline Computer Engineering & $\mathbf{3 9 . 9 5}$ & $\mathbf{p}=\mathbf{0 . 0 0 5}$ \\
\hline Civil Engineering & $\mathbf{5 0 . 3 0}$ & \\
\hline Chemical Engineering & 18.35 & $\mathrm{p}=0.008$ \\
\hline Mechanical Engineering & 28.65 & \\
\hline Food Engineering & $\mathbf{1 7 . 1 0}$ & $\mathbf{p}=\mathbf{0 . 0 1 4}$ \\
\hline Mechanical Engineering & $\mathbf{2 8 . 2 6}$ & \\
\hline
\end{tabular}

Students were asked about their tendency to recommend their department they are studying to younger generations. As clearly shown in Table 16, while the $\% 48$ of the students was high tendency to recommend the program they study to younger generations, $27 \%$ of them rated this tendency as low. Kruskal-Wallis test statistics indicated that many of the students in Civil Engineering (Mean Rank:125,19) propose their department they study to younger generations. This department is followed by Electrical \& Electronics Engineering Department (Mean Rank121,89) and Mechanical Engineering Department (Mean Rank:121,72), respectively.

Table 16. The tendency of undergraduate engineering faculty students' recommendation the program they study to younger generations

\begin{tabular}{|c|c|c|c|c|c|c|}
\hline \multirow[b]{2}{*}{ Department } & \multicolumn{6}{|c|}{ Department suggestion } \\
\hline & $\begin{array}{l}\text { Very } \\
\text { High }\end{array}$ & High & Average & Low & Very Low & Total \\
\hline Chemical Engineering & 1 & 4 & 9 & 4 & 5 & 23 \\
\hline Food Engineering & 4 & 3 & 3 & 3 & 7 & 20 \\
\hline Mechanical Engineering & 5 & 12 & 8 & 0 & 4 & 29 \\
\hline Computer Engineering & 10 & 13 & 15 & 5 & 11 & 54 \\
\hline Civil Engineering & 8 & 12 & 8 & 3 & 4 & 35 \\
\hline $\begin{array}{l}\text { Electrical and Electronics } \\
\text { Engineering }\end{array}$ & 16 & 23 & 12 & 11 & 5 & 67 \\
\hline Environmental Engineering & 0 & 0 & 1 & 2 & 0 & 3 \\
\hline Total & $44(19 \%)$ & $67(29 \%)$ & 56 & 28 & 36 & 231 \\
\hline
\end{tabular}

Mann-Whitney test statistic allowed to compare two independent sample comparisons to determine which departments were statistically different from each other in terms of their department suggestion. There is a statistically significant mean difference between Mechanical and Environmental Engineering students; Food and Electrical \& Electronics Engineering students; Chemical and Electrical \& Electronics Engineering students; Chemical and Civil
Engineering students; Food and Civil Engineering students; Chemical and Mechanical Engineering students; and Food and Mechanical Engineering students in terms of their tendency to recommend the program they study to younger generations. In addition, according to Mann-Whitney test statistic it can be said that Mechanical Engineering was highly recommended department by students compared to Chemical, Food and Environmental Engineering 
DOI: 10.29132/ijpas.354981

Departments. Similarly, Electrical\&Electronics and Civil Engineering Departments were substantially

more offered departments compared to Food and Chemical Engineering Departments.

\section{Mann-Whitney Test Statistics for Table 16}

\begin{tabular}{l|l|l}
\hline Department & Mean Rank & Significance \\
\hline Mechanical Engineering & $\mathbf{1 4 . 6 1}$ & $\mathbf{p}=\mathbf{0 . 0 3 1}$ \\
\cline { 1 - 2 } Environmental Engineering & $\mathbf{5 . 0 0}$ & \\
\hline Food Engineering & 29.93 & $\mathrm{p}=0.004$ \\
\hline Electrical and Electronics Engineering & 47.61 & \\
\hline Chemical Engineering & $\mathbf{3 2 . 8 9}$ & $\mathbf{p}=\mathbf{0 . 0 1 1}$ \\
\hline Electrical and Electronics Engineering & $\mathbf{4 8 . 3 7}$ & \\
\hline Chemical Engineering & 22.27 & $\mathbf{p}=\mathbf{0 . 0 1 3}$ \\
\hline Civil Engineering & 33.23 & \\
\hline Food Engineering & $\mathbf{2 0 . 2 7}$ & $\mathbf{0 0 . 0 0 6}$ \\
\hline Civil Engineering & $\mathbf{3 2 . 4 1}$ & $\mathbf{p}=0.016$ \\
\hline Chemical Engineering & 18.36 & \\
\hline Mechanical Engineering & 27.43 & $\mathbf{p}=\mathbf{0 . 0 1 4}$ \\
\cline { 1 - 2 } Food Engineering & $\mathbf{1 7 . 1 3}$ & \\
\hline
\end{tabular}

Students were asked whether the education received in the university would help them to achieve their professional goals. $27 \%$ of Mechanical Engineering, $25 \%$ of Civil Engineering, $25 \%$ of students Electrical and Electronics Engineering students had a high belief that the education they received would help to accomplish the objective they set (see Table 17).

Table 17. The belief that the education they receive in the university will reach their goals

\begin{tabular}{lcccccc}
\hline & \multicolumn{1}{c}{ Professional goal } \\
\hline & Very High & High & Average & Low & Very Low & Total \\
\hline Department & 1 & 2 & 9 & 8 & 3 & 23 \\
\hline Foomical Engineering & 0 & 1 & 5 & 9 & 5 & 20 \\
\hline Mechanical Engineering & 2 & 6 & 8 & 11 & 2 & 29 \\
\hline Computer Engineering & 4 & 4 & 14 & 19 & 13 & 54 \\
\hline $\begin{array}{l}\text { Civil Engineering } \\
\text { Electrical and Electronics }\end{array}$ & 3 & 6 & 12 & 8 & 6 & 35 \\
Engineering & 7 & 10 & 18 & 21 & 11 & 67 \\
Environmental Engineering & 0 & 0 & 2 & 1 & 0 & 3 \\
\hline Total & 17 & 29 & $68(29 \%)$ & $77(33 \%)$ & 40 & 231 \\
\hline
\end{tabular}

In addition, students were evaluated the proficiency level of the department program content they followed. As clearly shown in Table 18, students generally rated program content they followed as poor. 
Table 18. The adequacy of the program content of the departments

\begin{tabular}{lcccccc}
\hline & \multicolumn{3}{c}{ Program qualification level } \\
\hline & Very High & High & Average & Low & Very Low & Total \\
Department & 1 & 2 & 8 & 6 & 6 & 23 \\
\hline Chemical Engineering & 0 & 1 & 11 & 5 & 3 & 20 \\
\hline Food Engineering & 1 & 3 & 13 & 9 & 3 & 29 \\
\hline Mechanical Engineering & 2 & 2 & 22 & 13 & 15 & 54 \\
\hline Computer Engineering & 1 & 2 & 14 & 7 & 11 & 35 \\
\hline $\begin{array}{l}\text { Civil Engineering } \\
\text { Electrical and Electronics }\end{array}$ & 2 & 4 & 26 & 18 & 17 & 67 \\
Engineering & 0 & 1 & 2 & 0 & 0 & 3 \\
\hline Environmental Engineering & 7 & 15 & $96(41 \%)$ & $58(25 \%)$ & $55(24 \%)$ & 231 \\
\hline Total & &
\end{tabular}

Undergraduate engineering students rated their departments' laboratory qualification levels. $60 \%$ of the students who participated in the survey stated that they found the proficiency level of the laboratories very low and low (see Table 19).

Table 19. Level of laboratory qualification of departments

\begin{tabular}{|c|c|c|c|c|c|c|}
\hline \multirow[b]{2}{*}{ Department } & \multicolumn{6}{|c|}{ Laboratory Qualification Level } \\
\hline & Very High & High & Average & Low & $\begin{array}{l}\text { Very } \\
\text { Low }\end{array}$ & Total \\
\hline Chemical Engineering & 2 & 1 & 11 & 7 & 2 & 23 \\
\hline Food Engineering & 1 & 2 & 7 & 4 & 6 & 20 \\
\hline Mechanical Engineering & 1 & 5 & 11 & 8 & 4 & 29 \\
\hline Computer Engineering & 1 & 1 & 9 & 11 & 31 & 53 \\
\hline Civil Engineering & 0 & 5 & 8 & 10 & 12 & 35 \\
\hline $\begin{array}{l}\text { Electrical and Electronics } \\
\text { Engineering }\end{array}$ & 1 & 9 & 14 & 20 & 23 & 67 \\
\hline $\begin{array}{l}\text { Environmental } \\
\text { Engineering }\end{array}$ & 0 & 0 & 3 & 0 & 0 & 3 \\
\hline Total & 6 & 23 & $63(27 \%)$ & $60(26 \%)$ & $78(34 \%)$ & 230 \\
\hline
\end{tabular}

Mann-Whitney Test Statistics for Table 25 clearly indicated that Mechanical Engineering Department laboratories were found statistically more adequate than that of Computer, Electrical\&Electronis, and Civil Engineering departments. Similarly, Environmental, Chemical, Electrical\&Electronics, and Food Engineering laboratories were also statistically superior to the Computer Engineering Department laboratories. Lastly, Chemical Engineering laboratories were found more satisfactory by the students than Civil, Computer and Electrical\&Electronics Engineering laboratories. 
DOI: 10.29132/ijpas.354981

Mann-Whitney Test Statistics for Table 19

\begin{tabular}{|c|c|c|}
\hline Department & Mean Rank & Significance \\
\hline Mechanical Engineering & 51.04 & \multirow[t]{2}{*}{$p=0.00$} \\
\hline Computer Engineering & 28.79 & \\
\hline Environmental Engineering & 44.50 & \multirow[t]{2}{*}{$\mathrm{p}=0.034$} \\
\hline Computer Engineering & 24.71 & \\
\hline Mechanical Engineering & 54.57 & \multirow[t]{2}{*}{$\mathrm{p}=\mathbf{0 . 0 1 5}$} \\
\hline Electrical and Electronics Engineering & 40.20 & \\
\hline Chemical Engineering & 36.91 & \multirow[t]{2}{*}{$\mathrm{p}=0.005$} \\
\hline Civil Engineering & 24.63 & \\
\hline Chemical Engineering & 51.09 & \multirow[t]{2}{*}{$\mathrm{p}=\mathbf{0 . 0 0}$} \\
\hline Computer Engineering & 28.77 & \\
\hline Chemical Engineering & 54.76 & \multirow[t]{2}{*}{$\mathrm{p}=0.013$} \\
\hline Electrical and Electronics Engineering & 40.13 & \\
\hline Computer Engineering & 47.48 & \multirow[t]{2}{*}{$\mathrm{p}=\mathbf{0 . 0 0 6}$} \\
\hline Electrical and Electronics Engineering & 63.27 & \\
\hline Mechanical Engineering & 36.85 & \multirow[t]{2}{*}{$\mathrm{p}=0.005$} \\
\hline Civil Engineering & 24.67 & \\
\hline Food Engineering & 45.10 & \multirow[t]{2}{*}{$\mathrm{p}=\mathbf{0 . 0 0 2}$} \\
\hline Computer Engineering & 30.08 & \\
\hline
\end{tabular}

As for the relationship between the lecturer and the student, according to senior students the departments with the highest student-lecturer interaction were the Environmental Engineering

(66\%), Food Engineering (55\%), and Computer Engineering (55\%), respectively (see Table 20).

Table 20. Level of relationship between the lecturer and the student

\begin{tabular}{lcccccc}
\hline & \multicolumn{7}{c}{ Level of relationship between the lecturer and the student } \\
\hline & $\begin{array}{l}\text { Very } \\
\text { High }\end{array}$ & High & Average & Low & $\begin{array}{c}\text { Very } \\
\text { Low }\end{array}$ & Total \\
Department & 1 & 6 & 8 & 5 & 3 & 23 \\
\hline Chemical Engineering & 4 & 7 & 5 & 3 & 1 & 20 \\
\hline Food Engineering & 2 & 3 & 15 & 4 & 5 & 29 \\
\hline $\begin{array}{l}\text { Mechanical Engineering } \\
\text { Computer Engineering }\end{array}$ & 12 & 17 & 12 & 7 & 5 & 53 \\
\hline Civil Engineering & 2 & 4 & 8 & 12 & 9 & 35 \\
\hline $\begin{array}{l}\text { Electrical and } \\
\text { Engineering }\end{array}$ & 7 & 10 & 28 & 12 & 10 & 67 \\
\hline Environmental Engineering & 1 & 1 & 0 & 1 & 0 & 3 \\
\hline Total & 29 & $48(21 \%)$ & $76(33 \%)$ & $44(19 \%)$ & 33 & 230 \\
\hline
\end{tabular}

According to Mann-Whitney Test Statistics for Table 20, there is a statistically significant mean difference between Computer Engineering students and students in Electrical\&Electronics, Chemical, Civil and Mechanical Engineering in terms of the student/lecturer relationship in favor of Computer Engineering Department. Likewise, the level of lecturer/student relationship in Civil Engineering is statistically significant than the departments of Food and Chemical Engineering disfavor of Civil Engineering Department. The competence of the academic staff of the departments was also assessed by the students. The responses given by the students were compiled in Table 21. The competence of the instructors in Environmental Engineering and Chemical Engineering Departments carrying out the programs was found to be highest by the students. 
DOI: 10.29132/ijpas.354981

\section{Mann-Whitney Test Statistics for Table 20}

\begin{tabular}{l|l|l}
\hline Department & Mean Rank & Significance \\
\hline Computer Engineering & $\mathbf{6 7 . 0 9}$ & $\mathbf{p}=\mathbf{0 . 0 0 1}$ \\
\cline { 1 - 2 } Electrical and Electronics Engineering & $\mathbf{4 6 . 5 2}$ & \\
\hline Chemical Engineering & 27.36 & $\mathrm{p}=0.019$ \\
\hline Computer Engineering & 39.23 & \\
\hline Computer Engineering & $\mathbf{5 1 . 5 0}$ & $\mathbf{p}=\mathbf{0 . 0 0 0}$ \\
\cline { 1 - 2 } Civil Engineering & $\mathbf{2 8 . 9 7}$ & \\
\hline Mechanical Engineering & 26.85 & $\mathrm{p}=0.007$ \\
\hline Computer Engineering & 40.39 & \\
\hline Chemical Engineering & $\mathbf{3 4 . 5 9}$ & $\mathbf{p}=\mathbf{0 . 0 3 8}$ \\
\hline Civil Engineering & $\mathbf{2 5 . 4 9}$ & \\
\hline Food Engineering & 34.84 & $\mathrm{p}=0.009$ \\
\cline { 1 - 2 } Civil Engineering & 23.51 & \\
\hline
\end{tabular}

Table 21. The competence of the academic staff to carry out the program according to undergraduate students

The competence of the academic staff

\begin{tabular}{|c|c|c|c|c|c|c|}
\hline Department & Very High & High & Average & Low & Very Low & Total \\
\hline Chemical Engineering & 1 & 5 & 10 & 4 & 3 & 23 \\
\hline Food Engineering & 0 & 2 & 9 & 7 & 2 & 20 \\
\hline Mechanical Engineering & 0 & 6 & 13 & 9 & 1 & 29 \\
\hline Computer Engineering & 2 & 8 & 22 & 12 & 9 & 53 \\
\hline Civil Engineering & 0 & 1 & 14 & 11 & 9 & 35 \\
\hline $\begin{array}{l}\text { Electrical and Electronics } \\
\text { Engineering }\end{array}$ & 2 & 5 & 27 & 16 & 17 & 67 \\
\hline $\begin{array}{l}\text { Environmental } \\
\text { Engineering }\end{array}$ & 0 & 1 & 2 & 0 & 0 & 3 \\
\hline Total & 5 & 28 & $97(42 \%)$ & $59(25 \%)$ & 41 & 230 \\
\hline
\end{tabular}

Mann-Whitney Test Statistics for Table 27 indicated that there is a statistically significant mean difference between Civil Engineering and Environmental, Mechanical, Chemical Engineering departments disfavor of Civil Engineering Department in terms of the proficiency of academic staff to carry out the program. Moreover, it can be said that the competence of the faculty members of the Mechanical and Chemical engineering departments were found statistically more competent than those of the Electrical\&Electronics Engineering.

Perhaps the most important question was asked that whether the department they are studying provides a support in finding a job. In Table 23, senior students stated Electrical-Electronics, Food Engineering and Civil Engineering departments gave the students the greatest support for finding a job.
In general, the level of fulfillment of expectations from the education quality was investigated. When Table 24 was examined, it is obvious that the level of satisfaction of the education received in university to meet the expectations was lower in all departments. Despite, $33 \%$ of the Environmental Engineering students, $17 \%$ of the Mechanical Engineering students and $12 \%$ of the Electrical-Electronics Engineering students were fulfilled from the education quality given.

Students were asked to rate their belief that they would be able to find a job they desired after graduation. Senior Mechanical Engineer students had the highest belief that they would be able to find a desired job after graduation (see Table 22).

Mann Whitney Test Statistic for this question demonstrated that undergraduate Chemical Engineering students had statistically more fulfilled 
DOI: 10.29132/ijpas.354981

of the expectations from the education quality given compared to students studying at Civil Engineering, Electrical\&Electronics, Computer, Food Engineering Departments. In addition, Mechanical Engineering students in general have statistically more satisfied the expectations of the education they have received compared to Food and Computer Engineering students.

Students were asked to rate their beliefs that they could be an adequate engineer in their profession when they graduated. When the below Table 25 was observed, $41 \%$ of the students in the Department of Mechanical Engineering had a strong belief that they would be a qualified engineer when they graduated. The Department of Environmental Engineering (33\%), Department of Food Engineering (30\%), Department of Computer Engineering (28\%), Department of Civil Engineering (25\%), Department of Electrical and Electronics Engineering (21\%) follows the Mechanical Engineering Department, respectively.

\section{Mann-Whitney Test Statistics for Table 21}

\begin{tabular}{l|l|l}
\hline Department & Mean Rank & Significance \\
\hline Civil Engineering & $\mathbf{1 8 , 5 3}$ & $\mathbf{p}=\mathbf{0 , 0 4 8}$ \\
\cline { 1 - 2 } Environmental Engineering & $\mathbf{3 0 , 8 3}$ & \\
\hline Mechanical Engineering & 55,04 & $\mathrm{p}=0,015$ \\
\hline Electrical and Electronics Engineering & 40,77 & \\
\hline Mechanical Engineering & $\mathbf{3 6 , 2 0}$ & $\mathbf{p}=\mathbf{0 , 0 0 9}$ \\
\cline { 1 - 2 } Civil Engineering & $\mathbf{2 5 , 1 0}$ & \\
\hline Chemical Engineering & 55,80 & $\mathrm{p}=0,010$ \\
\hline Electrical and Electronics Engineering & 40,50 & \\
\hline Chemical Engineering & $\mathbf{3 6 , 5 7}$ & $\mathbf{p}=\mathbf{0 , 0 0 6}$ \\
\hline Civil Engineering & $\mathbf{2 4 , 8 6}$ & \\
\hline
\end{tabular}

Table 22. Belief that students would find jobs on the required condition after graduation

\begin{tabular}{lcccccc}
\hline & \multicolumn{7}{c}{ Belief in finding a job } \\
\hline & $\begin{array}{c}\text { Very } \\
\text { High }\end{array}$ & High & Average & Low & Very Low & Total \\
\hline Chemartment & 2 & 3 & 5 & 10 & 3 & 23 \\
\hline Food Engineering & 1 & 3 & 4 & 4 & 8 & 20 \\
\hline Mechanical Engineering & 3 & 6 & 8 & 8 & 4 & 29 \\
\hline Computer Engineering & 3 & 6 & 17 & 12 & 15 & 53 \\
\hline $\begin{array}{l}\text { Civil Engineering } \\
\text { Electrical and Electronics }\end{array}$ & 4 & 2 & 14 & 6 & 9 & 35 \\
Engineering & 6 & 7 & 28 & 14 & 12 & 67 \\
\hline Environmental Engineering & 0 & 0 & 2 & 1 & 0 & 3 \\
\hline Total & 19 & 27 & $78(34 \%)$ & $55(24 \%)$ & 51 & 230 \\
\hline
\end{tabular}

Table 23. Department support in getting a job after graduation

\begin{tabular}{lcccccc}
\hline & \multicolumn{7}{c}{ Department support for finding a job } \\
\hline Department & $\begin{array}{c}\text { Very } \\
\text { High }\end{array}$ & High & Average & Low & Very Low & Total \\
\hline Chemical Engineering & 0 & 1 & 7 & 9 & 6 & 23 \\
\hline Food Engineering & 1 & 2 & 2 & 6 & 9 & 20 \\
\hline Mechanical Engineering & 1 & 2 & 8 & 8 & 10 & 29 \\
\hline Computer Engineering & 1 & 4 & 12 & 10 & 26 & 53 \\
\hline Civil Engineering & 0 & 5 & 12 & 7 & 11 & 35 \\
\hline
\end{tabular}


DOI: 10.29132/ijpas.354981

\begin{tabular}{lcccccc}
\hline $\begin{array}{l}\text { Electrical and Electronics } \\
\text { Engineering }\end{array}$ & 4 & 8 & 10 & 17 & 28 & 67 \\
\hline Environmental Engineering & 0 & 0 & 3 & 0 & 0 & 3 \\
\hline Total & 7 & 22 & 54 & 57 & $90(39 \%)$ & 230 \\
\hline
\end{tabular}

Table 24. The level of fulfillment for expectations from the education quality

\begin{tabular}{|c|c|c|c|c|c|c|}
\hline & \multicolumn{6}{|c|}{ The level of fulfillment for expectations from the education quality } \\
\hline Department & $\begin{array}{l}\text { Very } \\
\text { High }\end{array}$ & High & Average & Low & Very Low & Total \\
\hline Chemical Engineering & 1 & 1 & 11 & 7 & 3 & 23 \\
\hline Food Engineering & 1 & 0 & 5 & 8 & 6 & 20 \\
\hline Mechanical Engineering & 0 & 5 & 12 & 6 & 6 & 29 \\
\hline Computer Engineering & 0 & 4 & 11 & 14 & 24 & 53 \\
\hline Civil Engineering & 1 & 1 & 10 & 13 & 10 & 35 \\
\hline $\begin{array}{l}\text { Electrical and Electronics } \\
\text { Engineering }\end{array}$ & 3 & 5 & 10 & 26 & 23 & 67 \\
\hline Environmental Engineering & 0 & 1 & 1 & 1 & 0 & 3 \\
\hline Total & 6 & 17 & 60 & $75(32 \%)$ & $72(31 \%)$ & 230 \\
\hline
\end{tabular}

Mann-Whitney Test Statistics for Table 24

\begin{tabular}{l|l|l}
\hline Department & Mean Rank & Significance \\
\hline Chemical Engineering & $\mathbf{5 4 . 0 9}$ & $\mathbf{p}=\mathbf{0 . 0 4 2}$ \\
\cline { 1 - 2 } Electrical and Electronics Engineering & $\mathbf{4 1 . 8 3}$ & \\
\hline Chemical Engineering & 34.76 & $\mathrm{p}=0.041$ \\
\hline Civil Engineering & 26.04 & \\
\hline Chemical Engineering & $\mathbf{4 5 . 3 7}$ & $\mathbf{p}=\mathbf{0 . 0 0 3}$ \\
\hline Computer Engineering & $\mathbf{3 0 . 6 7}$ & \\
\hline Mechanical Engineering & 44.33 & $\mathrm{p}=0.008$ \\
\hline Computer Engineering & 31.18 & \\
\hline Food Engineering & $\mathbf{1 8 . 0 5}$ & $\mathbf{p}=\mathbf{0 . 0 4 2}$ \\
\cline { 1 - 2 } Mechanical Engineering & $\mathbf{2 5 . 4 3}$ & \\
\cline { 1 - 2 } Chemical Engineering & 25.61 & $\mathrm{p}=0.031$ \\
\cline { 1 - 2 } Food Engineering & 17.85 & \\
\hline
\end{tabular}

Table 25. Students belief that they will be an adequate engineer when they graduate

\begin{tabular}{lcccccc}
\hline & \multicolumn{7}{c}{ Professional Competence } \\
\hline & $\begin{array}{c}\text { Very } \\
\text { High }\end{array}$ & High & Average & Low & $\begin{array}{c}\text { Very } \\
\text { Low }\end{array}$ & Total \\
\hline Chemical Engineering & 2 & 3 & 11 & 3 & 4 & 23 \\
\hline Food Engineering & 1 & 5 & 4 & 6 & 4 & 20 \\
\hline Mechanical Engineering & 3 & 9 & 6 & 7 & 4 & 29 \\
\hline Computer Engineering & 2 & 13 & 17 & 7 & 14 & 53 \\
\hline $\begin{array}{l}\text { Civil Engineering } \\
\text { Electrical and Electronics }\end{array}$ & 2 & 7 & 17 & 6 & 3 & 35 \\
Engineering & 4 & 13 & 15 & 18 & 17 & 67 \\
\hline Environmental Engineering & 0 & 1 & 1 & 1 & 0 & 3 \\
\hline Total & 14 & $51(22 \%)$ & $71(31 \%)$ & 48 & 46 & 230 \\
\hline
\end{tabular}


DOI: 10.29132/ijpas.354981

Students rated their beliefs that the education policy of the departments awakes the consciousness upon contemporary problems. About $66 \%$ of Environmental Engineering students, $45 \%$ of Food Engineering Department students, 36\% of Computer Engineering Students, 34\% of Chemical Engineering Department students, 33\% of Electrical and
Electronics Engineering Department students and 25\% of the students in the Department of Civil Engineering expressed that education policies of the departments help them to become aware of the problems of our time (see Table 26).

Table 26. The education policy that awakes the consciousness upon contemporary problems

\begin{tabular}{|c|c|c|c|c|c|c|}
\hline \multirow[b]{2}{*}{ Department } & \multicolumn{6}{|c|}{$\begin{array}{c}\text { The education policy that awakes the consciousness upon contemporary } \\
\text { problems }\end{array}$} \\
\hline & $\begin{array}{l}\text { Very } \\
\text { high }\end{array}$ & High & Average & Low & Very low & Total \\
\hline Chemical Engineering & 3 & 5 & 7 & 8 & 0 & 23 \\
\hline Food Engineering & 5 & 4 & 8 & 1 & 2 & 20 \\
\hline Mechanical Engineering & 2 & 7 & 11 & 7 & 2 & 29 \\
\hline Computer Engineering & 5 & 14 & 17 & 6 & 11 & 53 \\
\hline Civil Engineering & 4 & 5 & 15 & 5 & 6 & 35 \\
\hline $\begin{array}{l}\text { Electrical and Electronics } \\
\text { Engineering }\end{array}$ & 6 & 16 & 26 & 7 & 12 & 67 \\
\hline Environmental Engineering & 1 & 1 & 1 & 0 & 0 & 3 \\
\hline Total & 26 & $52(22 \%)$ & $85(37 \%)$ & 34 & 33 & 230 \\
\hline
\end{tabular}

And finally, students were asked to score their belief whether their department will be included in the professional occupational group within 10 years. Table 27 indicated that $62 \%$ of the students in the Mechanical Engineering Department, 60\% of the Electrical and Electronics Engineering Department students, $58 \%$ of the Computer Engineering Department students, $45 \%$ of the students of the Food Engineering Department, $42 \%$ of the students of the Civil Engineering Department students believed that their department would take place in the professional occupational group within 10 years.

Table 27. Undergraduate engineering students' beliefs that their department will be included in the professional occupational group within 10 years

\section{Professional Future}

\begin{tabular}{lcccccc} 
Department & Very high & High & Average & Low & Very low & Total \\
\hline Chemical Engineering & 4 & 1 & 8 & 8 & 2 & 23 \\
\hline Food Engineering & 4 & 5 & 4 & 0 & 7 & 20 \\
\hline Mechanical Engineering & 6 & 12 & 7 & 3 & 1 & 29 \\
\hline Computer Engineering & 16 & 15 & 5 & 5 & 12 & 53 \\
\hline $\begin{array}{l}\text { Civil Engineering } \\
\text { Electrical and Electronics }\end{array}$ & 7 & 8 & 12 & 3 & 5 & 35 \\
Engineering & 23 & 17 & 14 & 6 & 7 & 67 \\
\hline Environmental Engineering & 0 & 0 & 3 & 0 & 0 & 3 \\
\hline Total & $60(26 \%)$ & $58(25 \%)$ & $53(23 \%)$ & 25 & 34 & 230 \\
\hline
\end{tabular}

\section{DISCUSSION}

Universities around the world are now competing in both national and international arenas. In order to maintain students' satisfaction, all services that contribute to the academic life should be provided in an appropriate standard and student satisfaction should be increased. Student satisfaction surveys should be conducted on a regular basis and a university should tailor services accordingly, as they 
DOI: 10.29132/ijpas.354981

are the only referees for the success of the students. The course and instructor are the basic services provided by the university and determines the student's satisfaction with what happens in the lessons. The teaching they receive is perceived to be at an acceptable level largely conceals the shortcomings of physical possibilities. Even extensive studies have shown that many of the physical aspects of university services are not important to the satisfaction of the student (Douglas et al., 2006). Not only the mentioned newly-established university, but also the city where it is located does not offer physical activity in appropriate standards may have negative effect on students' satisfaction. In addition, the courses regarded one of the basic services of the university provided were criticized in terms of its competency and sufficiency level of its contents. As for the other basic service, teaching staffs were criticized in terms of the adequacy of their numbers, difficulty in reaching them and methods of teaching they used. As Missildine et al. (2013) mentioned that blending new teaching technologies with interactive classroom activities may lead to the development of lesson learning, but this does not always mean that student satisfaction will increase.

Negative responses of students to the questions in the survey did not mean that everything is going bad at this developing university. Sometimes you cannot meet their expectations if you give the best to the them. For instance, Boring et al. (2016) stated that student evaluations of teaching (SET) measures the satisfaction of students and class expectations more than measuring teaching effectiveness. While student satisfaction can contribute to the effectiveness of teaching, it is not itself teaching effectiveness. Students may or may not be satisfied with the lessons for reasons unrelated to the learning outputs, not controlled by the instructor (e.g., the instructor's gender). Therefore, it is necessary to know the perceptions of the students about the services provided by the institutions in order to understand the satisfaction and experience of them. Knowing the factors affecting student satisfaction is vital for the institution concerned with student expectation (Uddin et al., 2017).

Although student satisfaction is an important factor in determining the quality of learning and a significant factor in the success of learning programs, measurement of satisfaction for institutions can be used to evaluate courses and programs and helps predict student achievement up to a certain point (Aziz and Muhammad, 2017).

Education quality, social environment, scholarship facility, accommodation and safety, prestige and image are important forecasters of satisfaction (Arambewela and Hall, 2009). Based on the results of a comprehensive study of undergraduate students studying at the Faculty of Engineering at Munzur University, it is clear that students are not fully satisfied with the physical and academic services provided by the university.

\section{RECOMMENDATIONS}

Student satisfaction surveys such as this one can be applied by independent supervisors to the students at the end of each lesson, not just periodically. The results of the surveys can be delivered to the faculty members. In the light of the results, the instructor can make necessary arrangements in the method of teaching and the course content. Teaching staff whose courses are effective and efficient can also be rewarded.

\section{REFERENCES}

Athiyaman, A., 1997. Linking student satisfaction and service quality perceptions: the case of university education. European Journal of Marketing, 31(7):528-540.

Arambewela, R., Hall, J., 2009. An empirical model of international student satisfaction. Asia Pacific Journal of Marketing and Logistics, 21(4):555569.

Aziz, F.B., Muhammad, N.B., 2017. Student Satisfaction and Level of Acceptance with Blended Learning Environment. Advanced Journal of Technical and Vocational Education, 1(1):404-408.

Bini, M., Masserini, L., 2016. Students' Satisfaction and Teaching Efficiency of University Offer. Social Indicators Research, 129(2):847-862.

Boring, A., Ottoboni, K., Stark, P.B., 2016. Student evaluations of teaching (mostly) do not measure teaching effectiveness. ScienceOpen Research. (DOI:10.14293/S2199-1006.1.SOREDU.AETBZC.v1)

Browne, B.A., Kaldenberg, D.O., Browne, W.G., Brown, D.J., 1998. Student as customer: Factors affecting satisfaction and assessments of institutional quality. Journal of Marketing for Higher Education, 8(3):1-14.

Cheng, M., Taylor, J., Williams, J., Tong, K., 2016. Student satisfaction and perceptions of quality: testing the linkages for $\mathrm{PhD}$ students. Higher Education Research \& Development, 35(6):11531166. 
DOI: 10.29132/ijpas.354981

Çimen, M., 2015. Fen ve Sağlık Bilimleri Alanlarında SPSS Uygulamalı Veri Analizi, Palme Yayıncılık, Ankara.

Douglas, J., Douglas, A., Barnes, B., 2006. Measuring student satisfaction at a UK university. Quality Assurance in Education, 14(3):251-267.

Elliott, K. M., 2002. Key determinants of student satisfaction. Journal of College Student Retention, 4:271-279.

Elliott, K. Healy, M., 2001. Key factors influencing student satisfaction related to recruitment and retention. Journal of Marketing for Higher Education, 10:1-11.

Elliott, K. M., Shin, D., 2002. Student satisfaction: An alternative approach to assessing this important concept. Journal of Higher Education Policy and Management, 24(2):197-209.

Guolla, M., 1999. Assessing the teaching quality to student satisfaction relationship: Applied customer satisfaction research in the classroom. Journal of Marketing Theory and Practice, 7(3):87-97.

Poon, J., 2017. Examining graduate built environment student satisfaction in the UK. What matters the most? International Journal of Construction Education and Research,1-19.

Khosravi, A.A., Poushaneh, K., Roozegar, A., Sohrabifard, N., 2013. Determination of factors affecting student satisfaction if Islamic Azad University. Procedia Social and Behavioral Sciences, 84:579-583.

Lenton, P., 2015. Determining student satisfaction: An economic analysis of the National Student Survey. Economics of Education Review, 47:118-127.

Ling, K.C., Chai, L.T., Piew, T.H., 2010. The 'Inside-out' and 'Outside-in' Approaches on Students' Perceived Service Quality: An Empirical Evaluation. Management Science and Engineering, 4(2):01-26.

Marsh, H.W., Roche, L.A., 2000. Effects of grading leniency and low workload on students' evaluations of teaching: popular myth, bias, validity, or innocent by standers. Journal of Educational Psychology, 92(1):202-228.

Missildine, K., Fountain, R., Summers, L., Gosselin, K., 2013. Flipping the classroom to improve student performance and satisfaction. Journal of Nursing Education, 52(10):597-599.

Palacio, A.B., Meneses, G.D., Perez, P.J.P., 2002. The configuration of the university image and its relationship with the satisfaction of students. Journal of Educational Administration, 40(5):486-505.

Price, I. F., Matzdorf, F., Smith, L., Agahi, H., 2003. The impact of facilities on student choice of university. Facilities, 21(10):212-222.
Sapri, M., Kaka, A., Finch, E., 2009. Factors that influence student's level of satisfaction with regards to higher educational facilities services. Malaysian Journal of Real Estate, 4(1):34-51.

Singh, G., 2002. Educational consumers or educational partners: A critical theory analysis. Critical Perspectives on Accounting, 13(5):681-700.

Uddin, M. R., Mamun, A., Soumana, A. O., Khan, Md. M., 2017. Factors and Predictors of International Student's Satisfaction in Turkey. Educational Process: International Journal, 6(2):43-52.

Williams, J., 2013. Consuming higher education: Why learning can't be bought. London: Bloomsbury. 
DOI: 10.29132/ijpas.354981

Appendix 1. Undergraduate engineering students' department preference reason 1

\begin{tabular}{|c|c|c|c|c|c|c|c|c|c|c|c|c|}
\hline \multirow[b]{2}{*}{ Department } & \multicolumn{12}{|c|}{ Department preference reason 1} \\
\hline & $\begin{array}{l}\text { Suits my } \\
\text { talents }\end{array}$ & $\begin{array}{c}\text { To assess } \\
\text { the score, I } \\
\text { get from a } \\
\text { university } \\
\text { exam } \\
\end{array}$ & $\begin{array}{c}\text { Universi } \\
\text { ty } \\
\text { entrance } \\
\text { exam } \\
\text { score } \\
\end{array}$ & $\begin{array}{l}\text { Family- } \\
\text { oriented }\end{array}$ & $\begin{array}{l}\text { Ease of } \\
\text { finding a } \\
\text { job }\end{array}$ & $\begin{array}{l}\text { Opportunit } \\
\text { y to work } \\
\text { in the } \\
\text { public } \\
\text { sector } \\
\end{array}$ & $\begin{array}{l}\text { High } \\
\text { level of } \\
\text { income }\end{array}$ & $\begin{array}{l}\text { External } \\
\text { transfer } \\
\text { exam } \\
\text { (DGS) }\end{array}$ & $\begin{array}{c}\text { Family } \\
\text { profession }\end{array}$ & $\begin{array}{c}\text { Professi } \\
\text { onal } \\
\text { prestige }\end{array}$ & Others & Total \\
\hline $\begin{array}{l}\text { Chemical } \\
\text { Engineering }\end{array}$ & 6 & 5 & 2 & 3 & 4 & 0 & 0 & 2 & 0 & 0 & 1 & 23 \\
\hline Food Engineering & 4 & 5 & 7 & 0 & 1 & 1 & 0 & 0 & 0 & 2 & 0 & 20 \\
\hline $\begin{array}{l}\text { Mechanical } \\
\text { Engineering }\end{array}$ & 20 & 1 & 2 & 1 & 4 & 0 & 0 & 0 & 0 & 1 & 0 & 29 \\
\hline $\begin{array}{l}\text { Computer } \\
\text { Engineering }\end{array}$ & 28 & 9 & 5 & 5 & 1 & 0 & 1 & 0 & 0 & 2 & 3 & 54 \\
\hline Civil Engineering & 19 & 2 & 4 & 2 & 4 & 0 & 3 & 1 & 0 & 1 & 0 & 36 \\
\hline $\begin{array}{ll}\text { Electrical } & \text { and } \\
\text { Electronics } & \\
\text { Engineering } & \\
\end{array}$ & 32 & 6 & 5 & 11 & 5 & 4 & 0 & 0 & 1 & 1 & 1 & 66 \\
\hline $\begin{array}{l}\text { Environmental } \\
\text { Engineering }\end{array}$ & 0 & 2 & 0 & 1 & 0 & 0 & 0 & 0 & 0 & 0 & 0 & 3 \\
\hline Total & $\begin{array}{c}109 \\
(47 \%)\end{array}$ & $30(13 \%)$ & 25 & 23 & 19 & 5 & 4 & 3 & 1 & 7 & 5 & 231 \\
\hline
\end{tabular}


DOI: 10.29132/ijpas.354981

Appendix 2. Undergraduate engineering students' department preference reason 2

\begin{tabular}{|c|c|c|c|c|c|c|c|c|c|c|c|c|}
\hline \multirow[b]{2}{*}{ Department } & \multicolumn{12}{|c|}{ Department preference reason 2} \\
\hline & $\begin{array}{l}\text { Suits my } \\
\text { talents }\end{array}$ & $\begin{array}{l}\text { To assess } \\
\text { the score, } \\
\text { I get from } \\
\text { a } \\
\text { university } \\
\text { exam }\end{array}$ & $\begin{array}{l}\text { Universi } \\
\text { ty } \\
\text { entrance } \\
\text { exam } \\
\text { score }\end{array}$ & $\begin{array}{l}\text { Family- } \\
\text { oriented }\end{array}$ & $\begin{array}{l}\text { Ease of } \\
\text { finding a } \\
\text { job }\end{array}$ & $\begin{array}{l}\text { Opportunity } \\
\text { to work in the } \\
\text { public sector }\end{array}$ & $\begin{array}{l}\text { High } \\
\text { level of } \\
\text { income }\end{array}$ & $\begin{array}{l}\text { External } \\
\text { transfer } \\
\text { exam } \\
\text { (DGS) }\end{array}$ & $\begin{array}{c}\text { Family } \\
\text { professio } \\
\text { n }\end{array}$ & $\begin{array}{l}\text { Profession } \\
\text { al prestige }\end{array}$ & Others & Total \\
\hline $\begin{array}{l}\text { Chemical } \\
\text { Engineering }\end{array}$ & 1 & 7 & 5 & 1 & 2 & 1 & 3 & 2 & 1 & 0 & 0 & 23 \\
\hline Food Engineering & 4 & 1 & 5 & 1 & 3 & 0 & 2 & 1 & 1 & 1 & 1 & 20 \\
\hline $\begin{array}{l}\text { Mechanical } \\
\text { Engineering }\end{array}$ & 1 & 4 & 7 & 2 & 10 & 0 & 5 & 0 & 0 & 0 & 0 & 29 \\
\hline $\begin{array}{l}\text { Computer } \\
\text { Engineering }\end{array}$ & 1 & 2 & 11 & 4 & 12 & 5 & 2 & 0 & 2 & 13 & 1 & 53 \\
\hline Civil Engineering & 2 & 3 & 1 & 9 & 9 & 1 & 6 & 0 & 1 & 3 & 0 & 35 \\
\hline $\begin{array}{l}\text { Electrical and } \\
\text { Electronics } \\
\text { Engineering }\end{array}$ & 4 & 8 & 5 & 10 & 19 & 4 & 8 & 1 & 2 & 5 & 0 & 66 \\
\hline $\begin{array}{l}\text { Environmental } \\
\text { Engineering }\end{array}$ & 1 & 0 & 2 & 0 & 0 & 0 & 0 & 0 & 0 & 0 & 0 & 3 \\
\hline Total & 14 & 25 & $36(16 \%)$ & 27 & $55(24 \%)$ & 11 & 26 & 4 & 7 & 22 & 2 & 229 \\
\hline
\end{tabular}


DOI: 10.29132/ijpas.354981

Appendix 3. Undergraduate engineering students' department preference reason 3

\begin{tabular}{|c|c|c|c|c|c|c|c|c|c|c|c|c|}
\hline \multirow[b]{2}{*}{ Department } & \multicolumn{12}{|c|}{ Department preference reason 3} \\
\hline & $\begin{array}{c}\text { Suits my } \\
\text { talents }\end{array}$ & $\begin{array}{l}\text { To assess } \\
\text { the score, } \\
\text { I get from } \\
\text { a } \\
\text { university } \\
\text { exam }\end{array}$ & $\begin{array}{l}\text { Universi } \\
\text { ty } \\
\text { entrance } \\
\text { exam } \\
\text { score }\end{array}$ & $\begin{array}{l}\text { Family- } \\
\text { oriented }\end{array}$ & $\begin{array}{l}\text { Ease of } \\
\text { finding a } \\
\text { job }\end{array}$ & $\begin{array}{l}\text { Opportunity } \\
\text { to work in the } \\
\text { public sector }\end{array}$ & $\begin{array}{l}\text { High } \\
\text { level of } \\
\text { income }\end{array}$ & $\begin{array}{l}\text { External } \\
\text { transfer } \\
\text { exam } \\
(\text { DGS })\end{array}$ & $\begin{array}{l}\text { Family } \\
\text { professio } \\
\text { n }\end{array}$ & $\begin{array}{l}\text { Profession } \\
\text { al prestige }\end{array}$ & Others & Total \\
\hline $\begin{array}{l}\text { Chemical } \\
\text { Engineering }\end{array}$ & 3 & 3 & 2 & 0 & 6 & 1 & 4 & 0 & 0 & 4 & 0 & 23 \\
\hline Food Engineering & 1 & 3 & 2 & 1 & 2 & 2 & 3 & 1 & 0 & 3 & 2 & 20 \\
\hline $\begin{array}{l}\text { Mechanical } \\
\text { Engineering }\end{array}$ & 2 & 2 & 2 & 0 & 5 & 3 & 4 & 0 & 1 & 6 & 4 & 29 \\
\hline $\begin{array}{l}\text { Computer } \\
\text { Engineering }\end{array}$ & 6 & 3 & 3 & 2 & 4 & 7 & 15 & 1 & 1 & 7 & 4 & 53 \\
\hline Civil Engineering & 7 & 6 & 3 & 2 & 3 & 2 & 5 & 1 & 2 & 3 & 1 & 35 \\
\hline $\begin{array}{ll}\text { Electrical } & \text { and } \\
\text { Electronics } & \\
\text { Engineering } & \\
\end{array}$ & 2 & 5 & 9 & 2 & 6 & 2 & 11 & 4 & 5 & 15 & 4 & 66 \\
\hline $\begin{array}{l}\text { Environmental } \\
\text { Engineering }\end{array}$ & 1 & 0 & 1 & 0 & 1 & 0 & 0 & 0 & 0 & 0 & 0 & 3 \\
\hline Total & 22 & 22 & 22 & 7 & 27 & 17 & $42(18 \%)$ & 7 & 9 & $38(16 \%)$ & 15 & 229 \\
\hline
\end{tabular}


DOI: 10.29132/ijpas.354981

Appendix 4. The primary problem of the departments according to undergraduate students

\begin{tabular}{|c|c|c|c|c|c|c|c|}
\hline \multirow[b]{2}{*}{ Department } & \multicolumn{7}{|c|}{$\begin{array}{l}\text { Primary Department Problem } \\
\end{array}$} \\
\hline & $\begin{array}{c}\text { Lack of } \\
\text { infrastructure } \\
\text { (Classes, } \\
\text { buildings, etc.) }\end{array}$ & High quotas & $\begin{array}{c}\text { Professional } \\
\text { inadequacy of } \\
\text { faculty members }\end{array}$ & $\begin{array}{l}\text { Inadequacy of } \\
\text { field practice }\end{array}$ & $\begin{array}{c}\text { Lack of } \\
\text { laboratory }\end{array}$ & $\begin{array}{c}\text { Lack of } \\
\text { teaching staff }\end{array}$ & Total \\
\hline Chemical Engineering & 14 & 1 & 5 & 3 & 0 & 0 & 23 \\
\hline Food Engineering & 7 & 2 & 8 & 2 & 1 & 0 & 20 \\
\hline Mechanical Engineering & 11 & 3 & 8 & 6 & 0 & 1 & 29 \\
\hline Computer Engineering & 22 & 1 & 11 & 7 & 12 & 1 & 54 \\
\hline Civil Engineering & 8 & 3 & 18 & 5 & 1 & 0 & 35 \\
\hline $\begin{array}{l}\text { Electrical and Electronics } \\
\text { Engineering }\end{array}$ & 18 & 6 & 29 & 11 & 1 & 2 & 67 \\
\hline Environmental Engineering & 1 & 0 & 2 & 0 & 0 & 0 & 3 \\
\hline Total & $81(35 \%)$ & 16 & $81(35 \%)$ & 34 & 15 & 4 & 231 \\
\hline
\end{tabular}

Appendix 5. The secondary problem of the departments according to undergraduate students

\begin{tabular}{|c|c|c|c|c|c|c|c|}
\hline \multirow[b]{2}{*}{ Department } & \multicolumn{7}{|c|}{\begin{tabular}{|c|} 
Secondary Department Problem \\
\end{tabular}} \\
\hline & $\begin{array}{c}\text { Lack of } \\
\text { infrastructure } \\
\text { (Classes, } \\
\text { buildings, etc.) }\end{array}$ & High quotas & $\begin{array}{c}\text { Professional } \\
\text { inadequacy of } \\
\text { faculty members }\end{array}$ & $\begin{array}{l}\text { Inadequacy of } \\
\text { field practice }\end{array}$ & $\begin{array}{c}\text { Lack of } \\
\text { laboratory }\end{array}$ & $\begin{array}{c}\text { Lack of teaching } \\
\text { staff }\end{array}$ & Total \\
\hline Chemical Engineering & 1 & 0 & 1 & 17 & 4 & 0 & 23 \\
\hline Food Engineering & 0 & 0 & 1 & 12 & 7 & 0 & 20 \\
\hline Mechanical Engineering & 3 & 2 & 5 & 13 & 5 & 1 & 29 \\
\hline Computer Engineering & 1 & 0 & 9 & 8 & 22 & 14 & 54 \\
\hline Civil Engineering & 1 & 2 & 4 & 15 & 8 & 5 & 35 \\
\hline $\begin{array}{l}\text { Electrical and Electronics } \\
\text { Engineering }\end{array}$ & 1 & 0 & 10 & 25 & 16 & 15 & 67 \\
\hline Environmental Engineering & 1 & 1 & 0 & 0 & 1 & 0 & 3 \\
\hline Total & 8 & 5 & 30 & $90(39 \%)$ & $63(27 \%)$ & 35 & 231 \\
\hline
\end{tabular}


DOI: 10.29132/ijpas.354981

Appendix 6. Distribution of undergraduate engineering faculty students' occupational goals according to their departments

\begin{tabular}{|c|c|c|c|c|c|c|c|}
\hline \multirow[b]{2}{*}{ Department } & \multicolumn{7}{|c|}{ Occupational Goal } \\
\hline & $\begin{array}{c}\text { Work in private } \\
\text { sector }\end{array}$ & $\begin{array}{c}\text { Work in } \\
\text { public sector }\end{array}$ & $\begin{array}{c}\text { Having an academic } \\
\text { career }\end{array}$ & $\begin{array}{c}\text { Set up one's } \\
\text { own business }\end{array}$ & $\begin{array}{c}\text { Dealing with } \\
\text { something outside of } \\
\text { your own business }\end{array}$ & Undecided & Total \\
\hline Chemical Engineering & 10 & 3 & 3 & 6 & 1 & 0 & 23 \\
\hline Food Engineering & 9 & 7 & 3 & 0 & 0 & 1 & 20 \\
\hline Mechanical Engineering & 9 & 10 & 4 & 5 & 1 & 0 & 29 \\
\hline Computer Engineering & 14 & 21 & 9 & 7 & 1 & 2 & 54 \\
\hline Civil Engineering & 12 & 8 & 6 & 7 & 0 & 2 & 35 \\
\hline $\begin{array}{l}\text { Electrical and } \\
\text { Electronics Engineering }\end{array}$ & 26 & 10 & 8 & 17 & 1 & 5 & 67 \\
\hline Environmental Engineering & 2 & 0 & 0 & 1 & 0 & 0 & 3 \\
\hline Total & $82(35 \%)$ & $59(25 \%)$ & $33(14 \%)$ & 43 & 4 & 10 & 231 \\
\hline
\end{tabular}

